\title{
Mass Media and Religious Sentiment (A Discourse Analysis of Newspapers in Medan City)
}

\author{
Muhammad Thariq \\ University of Muhammadiyah Sumatera utara(UMSU) \\ Email: muhammadthariq@umsu.ac.id
}

\begin{abstract}
The study in this study used a discourse text analysis model to find out and explain the positions of three wary, Analysis and Sinar Indonesia Baru (SIB) newspapers in presenting the issue of the collapse of Al-Ikhlas Mosque at Timor Medan throughout 2012. This study also wanted to know the policy process media in determining one news that will be presented to the reader including determining the issue, title, content of news, paragraphs, placement of news and news sources, especially related to the presentation of the news of the mosque's collapse. The goal is to look at the three newspaper mechanisms examined in producing news, journalists' relations with the media and media editors managing the news. The unit of analysis studied is news of events / hard (straight news / hard news) and news of interviews or analysis (news analysis). Researchers used the main theories of media discourse structure, media construction and media cognition from van. This research was carried out with three steps namely text, social cognition and context. In the text study, the researcher used two methods: analyzing the content with quantitative-descriptive and analyzing the framing of Robert Entmann. From the results of news framing, researchers conducted an in-depth interview with the editor in chief / editor of each newspaper studied to uncover and strengthen the results of the study as in the van Dijk model media text analysis phase. Interviews were conducted to determine the editorial / journalist's social cognition processes in the wary, Analysis and Sinar Indonesia Baru newspapers in constructing and interpreting the news of the collapse of the Al-Ikhlas Mosque. The results obtained from the three newspapers about the study were discourses framed by three newspapers about the news of the collapse of the Al-Ikhlas Mosque which had a difference: first, the wary Daily expressed the truth with the background of the case problem so that it clearly showed its attitude against the mosque collapse. whereas Analysis and Sinar Indonesia Baru are more "safe looking". Secondly, the Daily wary, Analysis, and Sinar Indonesia Baru in constructing the collapse of the Al-Ikhlas mosque are strongly influenced by the background of the newspaper and its readers, and the editor's interpretation is influenced by religious and ethnic sentiments of the newspaper owner's background to strengthen the wary (Islam) Daily ideology. Analysis (ethnic Chinese) and Sinar Indonesia Baru (Christians) in the midst of the community which ultimately makes inconsistencies in the meaning and delivery of messages from the reality of the destruction of the Al-Ikhlas Mosque to the reader.
\end{abstract}

Keyword: Mass Media; Religious; Religious Sentiment 


\section{Introduction}

The newspaper was published in Medan City, the Capital City of North Sumatra Province, Indonesia, part of a national newspaper that could not escape the competition of the media and the media industry with a network of powerful and enthusiastic investors. For this reason, media that have a reader base such as the Waspada Daily, the Daily Analysis and the New Sinar Indonesia Daily (SIB) further reinforce and sharpen the reader segment by highlighting the power and ideology inherent in each of the newspapers. The power and ideology inherent in the three newspapers not only maintains the market base of the readers of each Muslim (Waspada), Chinese/ business (Analysis) and Batak-non-Muslim (Sinar Indonesia Baru/ SIB), also feels able to form opinions and influence the public agenda in various issues that are broadcast, whether the issues are packed in headline or non-headline news, news analysis, hard news, soft news or features etc. For this reason, three public newspapers that have been established for a long time have been able to survive in the midst of exposure to low-priced newspaper competition which is claimed to have gained market share for readers after more than two stands in Medan such as the Tribune (Kompas Group).

According to Eriyanto (2001), the domination and ideology that the media implanted, made the media-industry reader community as entered into symbolic hypermarkets. Indeed, there is something new in the press in the country and the symbolic reality it produces. There is something that is no longer the same as in the politics of our media industry consumers. Some of these changes are legitimate things to celebrate. Still in Eriyanto, the basis of the production system that gave birth to the texts of our media content remains the same as well, namely that which is driven by the dynamics of the never-ending circuit of capital accumulation or syringe money commodity more money. While the superstructure of production of all texts itself is now increasingly evident filled with a strange concoction, the result of a combination of formal rationality, namely instrumental rationality for the purpose of maximizing profits and capital accumulation in the frame of a metanarrage that sees the inequality of social structure as a natural thing. With rationality of substance that can be easily filled with patriarchal ideologies and racialist sentiments, religion, domination, power and primordialism.

According to Eriyanto (2001), at this time there was a long party when we entered the reform era until now the release of the press from the shackles of the New Order's power, the press has changed character into a free-tempered press that is skilled at producing critical, racial, primordialism texts domination and ideology towards the government or other power figures in raising certain issues. While consumers must have complete freedom to choose while interpreting all texts sold by newspapers. The most important thing to understand is the difference between the power of the text and the power over the structure in which the text is constructed, presented and interpreted. This means that consumers and press workers do indeed have the choice of how to make and interpret the text, but that is not done in the frame of the structure of the choices they make themselves, but that which forms outside the scope of their intervention. The structure of the text, the system of production, rationality, domination and ideology that play a role in the 
production of text are often not bare enough to be recognized. It takes its own efforts and methods to explore and reveal structures, rationality and hidden ideologies to influence the public agenda, culture, politics and policy agenda. Thus it can be known how the structure of the compilation of news that is carried out, produced and misused (Aris Badara, 2012: 29-35). In this case the media seems to be an instrument that justifies acting emotionally for the group's own victory which leads to clashes between protestors and police officers, disrupting public facilities and unconsciously vilifying ethnicity. In this context, the authors take the object of news research in the Waspada, Analysis and Sinar Indonesia Baru Daily (SIB) related to the event of a mosque collapse in Medan City which had sparked the anger of Muslim elements and ignited social conflicts and even led to the issue of ethnicity, religion, race (SARA ) which continuously broadcast the three media above continuously. This issue surfaced in mid-2011 and it was marked by demonstrations in January-May 2012 starting with the action of the Al-Ikhlas Mosque on at Timor by the Regional Military Command (Kodam) I/ Bukit Barisan. Kodam I/ BB claimed that the mosque was standing on land (assets) of the Kodam which incidentally belonged to the state and mosque collapses were later revealed regarding the transfer of state assets into the hands of businessmen or developers. Sentiment towards religion also sparked protests against mosque demolitions because the issue touched on and smelled of business and city development interests by private ethnic Chinese non-Muslims labeled as capitalist groups accused by protesting elements of wanting to flatten mosque retreats to be used as property .

In addition, the Commander of the I / BB Military Regional Command at that time was held by a non-Muslim. Not long after this event occurred, non-Muslim officials were replaced by Muslims. Therefore, the news in the three newspapers above is important for the writer to be reviewed and revealed to see the preparation of the text in the news discourse compiled and lead to the formation of reality construction on the issues that occur by each newspaper. For this reason, researchers expect to know how the elements of action, context, power, ideology and history in the mass media are practicable and may be misused, even injustice through text games. According to Saverin and Tankard (2008: 266), the issues raised through the selection process to be conveyed to the public are strongly believed that the media agenda influences the public agenda and policy agenda. The study of how mosque collapse discourse is transferred to print media becomes a news starting from a normative footing. Why is the problem crucial? The mosque as a religious symbol however has its own territory that cannot be compared with other regions such as business interests in human life. Secular and non secular territorial division shows that religious life, even though in reality it is difficult and does not need to be separated from daily life. Hoover in Dedi Mulyana and Solatun (2007: 345) said that religious symbols are explicitly related to ontological dimensions and dimensions of being experienced with creatures and meanings. Religion presents meaning to the existence of individuals in a greater cosmic significance/ meaningfulness, while mass media, especially newspapers, have long been suspected of being cultural agents that carry market interests. Any news in the newspaper, whatever the idealism he engages in the reader is nothing more than an extension of market culture with the logic of capitalism moving behind him. But all this certainly does not go alone and cannot exist by itself. The market is a construction of every party involved in the vicinity. This is what will undoubtedly occur in the construction of newspaper reporting. When the news 
of the collapse of the Al-Ikhlas Mosque on Timor Medan was dominated by certain religions and ethnicities of the respective media owners and readers, it was interesting to analyze the interplay between each actor and agents in the media as a space for symbolic reality.

\section{Methods of The Research}

\subsection{Research Methods and Design}

This research focuses on studies around the meaning of a concept of the collapse of the Al-Ikhlas Mosque on Timor Medan which produces certain texts and media work processes. As the flow of proof is reversed, this study begins at the text level to identify whether there is an inconsistency of meaning occurring, followed by an analysis of the levels that question why the question behind the text appears. Using qualitative methods, the foundation is considered appropriate for designing research designs. Thus van Dijk's discourse analysis involves three structures: text, social cognition and social context. Because the study discusses the language of the text so that discourse analysis is used with "knife" van Dijk's analysis, so that the following things are taken into account:

a. To take into account the meaning of the text rather than the sum of the category units, even though there are mapping of issue categories, news volume, number of paragraphs, columns and placement of news pages that are the object of research in three newspapers. It was only to give an idea of how much related news was published in three newspapers. Therefore, researchers still rely on interpretation and interpretation. This is in accordance with discourse analysis which is part of the interpretative method (Eriyanto, 2010).

b. Researchers use van Dijk's model which consists of 3 (three): macro, micro and social cognition levels.

c. The researcher conducts interviews to gather information from journalists / editors who reduce the news, so as to uncover the aspects of context and social cognition contained in the news text analyzed. Researchers do not intend to generalize on the contents of the text and context, but they are all based on the various rationale and discourse analysis framework of Tun A. van Dijk. (Eriyanto, 2011).

d. The researcher does not intend to generalize the contents of the text and context, but it is all based on various thoughts and the framework of the discourse analysis of Tun A. van Dijk. (Eriyanto, 2011). The analytical approach used is a critical approach, which is an approach that examines and uncovers aspects hidden behind a visible reality (virtual reality) for criticism and change. Through Robert Antmann's view, the study of framing is very good when using quantitative in the form of a view table that reflects the frequency and percentage.

\subsection{Data Source}

\section{a. Primary data:}

The main source in the news that was used as the unit of analysis was the researchers used interviews with the editor in chief / Waspada Daily Editor, Analysis and Sinar Indonesia 
Baru related to the news of the Masjid Al-Ikhlas collapse on the Medan Road throughout 2012.

b. Secondary Data:

As for secondary data, researchers conducted a literature study by compiling all published editions throughout 2012 from the documentation section of the Waspada Daily, Analysis and Sinar Indonesia Baru (SIB)

\subsection{Data Collection and Recording Procedures}

Research data collection is carried out through the following stages:

a. Searching for sources of written data in newspapers reporting on the collapse of the $\mathrm{Al}$ Ikhlas Mosque which peaked during January to May 2012.

b. Determine 3 (three) news of the collapse of Al-Ikhlas Mosque on Timor Street in Waspada, Analysis and Sinar Indonesia Baru Daily to be framed by van Dijk's model. The three news items were selected based on descriptive quantitative categorization of 18 news collected throughout 2012. Thus each newspaper had 1 (one) news selected from 18 news. From the purposive method, 18 news stories or 6 (six) news from each newspaper are sufficient as adjusted to Stamp taboo in Aris Badara (2011), which says six samples can produce significant results, provided that they are used in newspapers that use the same size and distribution of contents are similar. For this reason the researcher chooses and determines each categorization that gets the largest portion of the categorization and the other three types of news are hard news and types of news analysis. The reason researchers took the news as an object of research accordingly (Mc Quail, 1991: 34) and (Jalaluddin Rakhmat, 2007: 90) that information contains news value and is considered important and has media interests and public agenda, if the message and news contain elements of community and the most decisive categorization and context of quantitative content. In this case quantitative analysis is descriptive. From this news researchers want to see behind the text of the Waspada Daily, Analysis and Sinar Indonesia Baru news about the event of the collapse of the Al-Ikhlas Mosque in Timor Medan Street.

c. After going through the text analysis stage based on the text analysis approach of van Dijk framing, an in-depth interview was held with the editor in chief / editor of Waspada Daily, Daily Analysis and Sinar Indonesia Baru Daily by using a tape recorder to be transcribed as it should. After that the researcher showed the results of the interviews that had been made to the editor in chief of each newspaper investigated to obtain approval by affixing the results of the transcripts. This is what is called authenticity. Originality of data or in terms of estimating internal validity / validity of research data (Kriantono, 2012).

d. Recording interviews with the editor / redakur leader after first asking for confirmation to conduct an interview. Previous sources were informed about the purpose of the interview. Researchers still prepare material and guidelines for in-depth interviews, so that the interview results remain focused on the issues discussed.

\section{Results and Analysis}




\subsection{Research Process}

This research model uses van Dijk text analysis with a qualitative approach using the content analysis techniques of framing with the most news categorization techniques for framing and the context of quantitative content in this case quantitative analysis is descriptive. From this news researchers want to see behind the text of the Waspada Daily, Analysis and Sinar Indonesia Baru news about the event of the collapse of the Al-Ikhlas Mosque in Timor Medan Street. The van Dijk model uses 3 (three) levels namely micro, macro and social cognition by using discourse structures that are observed such as thematic covering themes/ topics that are put forward in a news; schematic includes how parts and sequences of news are highlighted in whole news texts; semantics include the meaning that you want to emphasize in the news text; syntax includes the selected sentence (form, structure); stilistics includes the choice of words used in news and rhetorical texts including how the emphasis is done. (Eriyanto, 2011: 228). Because the researchers collected 18 news throughout 2012 about the event of the collapse of the Al-Ikhlas Mosque on Timor Medan published in Waspada, Analysis and Sinar Indonesia Baru, the description was very long and it was feared that it would obscure the context under study. For this reason the researcher takes and forms a text analysis using Robert Entmann's framing analysis model and purposive method. This method is a combination of discourse analysis and framing analysis that is significant enough to establish news samples from 18 news throughout 2012 to show complete text, context and social cognition. In the text analysis research, there are two stages, namely quantitative content analysis and framing analysis. This is in line with the thoughts of Golding and Murdock (1977) and van Dijk (Jensen \& Jankowsky (eds), 1991. First, starting with quantitative text analysis then conducted qualitatively [discourse analysis, specifically framing methods belonging to Robert Entmann (1998), Hanson (1996), Price (1995) and also Lejeki (1993) The researcher cited the dissertation of Syafruddin Pohan (2010), stating that quantitative content with framing analysis (qualitative discourse) is quantitative content analysis focusing on the contents of real communication texts. Thus, framing analysis uses more interpretive analysis, it can be said that discourse analysis here is carried out in two stages, namely quantitative data retrieval using text content analysis and qualitative analysis for dynamic rhetoric framing.

\subsection{Analysis of the contents of the Waspada Daily, Analysis and Sinar Indonesia Baru}

In the research phase, the news texts in the Waspada Daily, Analysis and Sinar Indonesia Baru begins were carried out by analyzing the contents of each type of news which was the object of research, namely categorizing news of the collapse of Al Ikhlas Mosque on Jalan Timor Medan published in Harian Waspada, Analysis and SIB throughout 2012. news that has been collected will be an analysis unit using coding and choice according to recording sheet. In this way a category is made as is usual in the content analysis procedure. Categorization of reporting on the collapse of Al Ikhlas Mosque on Timor Medan as follows: 
1. The number of news of the collapse of the Al-Ikhlas Mosque, the Medan Timor Street, which was published in the Waspada Daily, Analysis and Sinar Indonesia Baru. Technically the number of numbers on the recording sheet is at the same time as a news number.

2. Position of news placement on the front page. Each newspaper is given an identification of the news category, which is displayed on the front page and other pages while considering the strategic position both the place and the headline are associated with the urgency of the news.

3. The number of paragraphs used by Waspada, Analysis and Sinar Indonesia Baru newspapers. The number of paragraphs in the news of each of the three newspapers will be described. This is to see how serious and intensive one newspaper is to pay attention to the issue of the collapse of the Al-Ikhlas Mosque on Timor Medan. To facilitate the identification of the number of paragraphs, each paragraph usage is identified with the range of each paragraph with the provisions starting at 1-5, 6-10,11-15, 16-20, 21-25 or more. Identify this to see which newspapers broadcast the longest news in news content placement.

4. Types of News. In this case the news will be grouped by three newspapers each. In this connection news grouping is divided into two categories:

a) News of events / current (straight news / hard news): news that contains current events or events that are very shocking (Assegaf, 1999). Usually this news is directly covered by reporters to the scene.

b) News analysis / interview (news analysis): news which is a follow-up analysis of an event that is reported back by journalists. The element of subjectivity is very obvious and tends to be the opinion of journalists and resource persons (thesis Syafruddin Pohan, 105)

5. News Source: every news certainly has a source of news which is used as information in a news, of course in relation to the news of the collapse of Al-Ikhlas Mosque on Timor there are government, mass organizations / OKP / individuals and legislative.

6. The main issue raised: The issues that were most raised and raised in the news of the collapse of the Al-Ikhlas Mosque on Timor Street in the Waspada Daily, Analysis and Sinar Indonesia Baru will be made into certain categories of material. The collection and grouping of these issues considers the balance of the three newspapers that have different perspectives in proclaiming the collapse of the Al-Ikhlas mosque.

Table 1. News Analysis Unit in Waspada Daily

\begin{tabular}{|c|c|r|c|c|}
\hline NO & EDITION & TITLE & THING & RUBRIK \\
\hline 1. & 6 Januari 2012 & $\begin{array}{c}\text { Acting Governor of North Sumatra: } \\
\text { Make the Mosque a Character } \\
\text { Building; The Military Commander } \\
\text { I / BB asks not to be rented out }\end{array}$ & 1 & Headlines \\
\hline
\end{tabular}




\begin{tabular}{|c|c|c|c|c|}
\hline 2. & 7 Januari 2012 & $\begin{array}{c}\text { Hundreds of Muslims Demo Mayor's } \\
\text { Office; Demand the Construction of } \\
\text { Al-Ikhlas Mosque at its Initial } \\
\text { Location }\end{array}$ & A3 & $\begin{array}{l}\text { Metropolitan } \\
\text { Medan }\end{array}$ \\
\hline 3. & 17Februari2012 & $\begin{array}{c}\text { Al-Ikhlas Mosque Will Be Built } \\
\text { Again }\end{array}$ & 1 & Headlines \\
\hline 4. & 18Februari2012 & $\begin{array}{c}\text { Al-Ikhlas Mosque Construction Must } \\
\text { Be Supervised }\end{array}$ & 1 & Headlines \\
\hline 5. & 22Februari2012 & $\begin{array}{l}\text { Al-Ikhlas Mosque Construction } \\
\text { Committee Urges Mayor May Revise } \\
\text { Management; Laying of the First } \\
\text { Stone March 1, } 2012\end{array}$ & A4 & $\begin{array}{c}\text { Medan } \\
\text { Metropolitan }\end{array}$ \\
\hline 6. & 16 Mei 2012 & Al-Ikhlas Mosque was rebuilt & 1 & Headlines \\
\hline
\end{tabular}

Table 2. Daily News Analysis Unit Analysis

\begin{tabular}{|c|c|c|c|c|}
\hline $\mathrm{NO}$ & EDITION & TITLE & THING & RUBRIK \\
\hline 1 & 7 Januari 2012 & $\begin{array}{l}\text { Hundreds of Masses of Islamic } \\
\text { Mass Organizations Ask the Al } \\
\text { Ikhlas Mosque to be Built at the } \\
\text { Initial Location }\end{array}$ & 4 & City \\
\hline 2 & 4 Februari 2012 & $\begin{array}{l}\text { The Alliance of Islamic } \\
\text { Organizations Again } \\
\text { Demonstrated the Emerald } \\
\text { Garden Hotel }\end{array}$ & 4 & City \\
\hline 3 & 7 Februari 2012 & $\begin{array}{l}\text { Don't Blaspheme and Certain } \\
\text { Ethnic Discredit in Demonstrating }\end{array}$ & 4 & City \\
\hline 4 & 10 Februari 2012 & $\begin{array}{c}\text { God's Servants Help the } \\
\text { Construction of Timor Street } \\
\text { Mosque }\end{array}$ & 4 & City \\
\hline 5 & 20 Februari 2012 & $\begin{array}{l}\text { Chairman of the Medan City } \\
\text { DMI: The Case of a Mosque } \\
\text { Destruction Has Never Occurred }\end{array}$ & 11 & City \\
\hline 6 & 16 Mei 2012 & $\begin{array}{l}\text { The Commander Puts the First } \\
\text { Stone on the Construction of Al- } \\
\text { Ikhlas Mosque }\end{array}$ & 9 & City \\
\hline
\end{tabular}

Source: processed from research data

Table 3. New Indonesian News Sinar Analysis Unit 


\begin{tabular}{|c|c|c|c|c|}
\hline $\begin{array}{c}\mathrm{N} \\
\mathrm{O}\end{array}$ & EDITION & TITLE & THING. & RUBRIK \\
\hline 1 & 7 Januari 2012 & $\begin{array}{c}\text { The Alliance of North Sumatra Islamic } \\
\text { Community Organizations in Medan } \\
\text { Pemko Protest Demo }\end{array}$ & 2 & \\
\hline 2 & 4 Februari 2012 & $\begin{array}{c}\text { Hundreds of Masses of the Islamic } \\
\text { Alliance of North Sumatra } \\
\text { Demonstration in front of the Emerald } \\
\text { Garden Hotel }\end{array}$ & 2 & Headlines \\
\hline 3 & 11 Februari 2012 & $\begin{array}{c}\text { Again, Mass Demo in front of the } \\
\text { Emerald Garden Hotel }\end{array}$ & 1 & \\
\hline 4 & 3 Maret 2012 & $\begin{array}{c}\text { Mosque Demolition Protest Demo at } \\
\text { the Mayor's Office Colored by } \\
\text { Incidents, 4 Protesters were Burned; } \\
\text { Demonstration in front of the Emerald } \\
\text { Garden Hotel Unrest }\end{array}$ & 15 & Headlines \\
\hline 5 & 10 Maret 2012 & $\begin{array}{c}\text { The Head of the Provincial Police } \\
\text { Directly Dropped into the Field, } \\
\text { Requesting a Mass Demo of Non- } \\
\text { Anarchist Islamic Organizations }\end{array}$ & 1 & \\
\hline 6 & 16 Mei 2012 & $\begin{array}{c}\text { The Commander I BB Puts the First } \\
\text { Stone on the Construction of a Mosque } \\
\text { on Jalan Timor Medan }\end{array}$ & 14 & \\
\hline
\end{tabular}

Source: Processed from research data

Table 4. News Placement

\begin{tabular}{|c|c|c|c|c|c|c|}
\hline $\begin{array}{c}\text { PLACEMEN } \\
\text { T } \\
\text { NEWS }\end{array}$ & $\begin{array}{c}\text { FREK. } \\
\text { wary }\end{array}$ & $\begin{array}{c}\text { PERSEN } \\
\%\end{array}$ & $\begin{array}{c}\text { FREK. } \\
\text { Analysis }\end{array}$ & PERCENT & $\begin{array}{c}\text { FREK. } \\
\text { SIB }\end{array}$ & PERCENT \\
\hline Main page & 4 & 67 & - & - & 2 & 33 \\
\hline Others & 2 & 33 & 6 & 100 & 4 & 67 \\
\hline total & 6 & 100 & 6 & 100 & 6 & 100 \\
\hline
\end{tabular}

Source: Processed from research data

Table 4 shows a comparison of the three newspapers in the placement of the news of the collapse of the Al-Ikhlas Mosque on Timor Medan. For example, the Waspada Daily puts the four news stories on the front page. Even from the newspaper analysis unit data above, not only are the four news items placed on the front page but three of them are made headlines on the page with a frequency of 4 percent 67 percent, the rest of the news is placed in the inner page but remains a headline according to the analysis unit data above while Daily Analysis has absolutely nothing to put the news on the front page but only placed on pages in other categories with frequency 6 . While SIB there are still two news items placed on the main page with 33 percent remaining on the page in 67 percent of each frequency respectively 2 and 4 . This certainly cannot be separated from the agenda setting (agenda setting) and the construction of the three daily studies on the issue. The purpose of the setting agenda remains inseparable from the formation of 
a public agenda. From this it was illustrated how the three media considered the collapse of the Al-Ikhlas Mosque from several sides of the media, readers and relations.

Table 5. Number of Paragraphs

\begin{tabular}{|c|c|c|c|c|c|c|}
\hline $\begin{array}{c}\text { Total } \\
\text { PARAGRAF }\end{array}$ & $\begin{array}{c}\text { FREK. } \\
\text { Wary }\end{array}$ & PERCENT\% & $\begin{array}{c}\text { FREK. } \\
\text { Analysis }\end{array}$ & PERCENT\% & $\begin{array}{c}\text { FREK. } \\
\text { SIB }\end{array}$ & $\begin{array}{c}\text { PERCENT } \\
\%\end{array}$ \\
\hline $1-5$ & - & & 1 & 17 & - & - \\
\hline $6-10$ & - & & 3 & 50 & 3 & 50 \\
\hline $11-15$ & 3 & 50 & - & - & 3 & 50 \\
\hline $16-20$ & 2 & 33 & 2 & 33 & - & - \\
\hline $21-25$ & - & - & - & - & - & - \\
\hline $26-30$ & 1 & 17 & - & - & - & - \\
\hline Jumlah & 6 & 100 & 6 & 100 & 6 & 100 \\
\hline
\end{tabular}

Source: Processed from research data

The description from table 5 above shows that the Waspada daily provides a fairly long portion of paragraphs on one news reaching the length of paragraphs 26-30. This is not found in the Analysis and SIB. Analysis and SIB tend to be the same in the placement of short paragraphs in the long classification of paragraphs 1-5 and 6-10. Although SIB together presents short paragraphs in sizes 11-15. From the above data it is clear, Waspada is more inclined to maintain and reject the mosque straightforwardly, while the Analysis and SIB is more on following the event for the benefit of the group / reader without being accompanied by an embedded ideology and not related to the mosque. This can be seen from the placement of the news Analysis and SIB is almost the same at length 5-10 and 11-15, while Waspada does not exist. This is in line with the ideological theory by Althusser saying that the length of the short text is a manifestation of the media ideology.

Table 6. News Type

\begin{tabular}{|c|c|c|c|c|c|c|}
\hline $\begin{array}{c}\text { TYPE } \\
\text { NEWS }\end{array}$ & $\begin{array}{c}\text { FREK. } \\
\text { Wary }\end{array}$ & PERCENT & $\begin{array}{c}\text { FREK. } \\
\text { Analysis }\end{array}$ & PERCENT & $\begin{array}{c}\text { FREK. } \\
\text { SIB }\end{array}$ & PERCENT \\
\hline $\begin{array}{c}\text { Straight } \\
\text { News }\end{array}$ & 1 & 17 & 2 & 33 & 5 & 83 \\
\hline $\begin{array}{c}\text { News } \\
\text { Analysis }\end{array}$ & 5 & 83 & 4 & 67 & 1 & 17 \\
\hline Total & 6 & 100 & 6 & 100 & 6 & 100 \\
\hline
\end{tabular}

Source: Processed from research data

In table 6 shows the most SIB puts news of events (straight news) with a frequency of 5 and 83 percent, the second analysis is 33 percent while Waspada is only 17 percent. Likewise, none of the three media were 100 percent or dominant in the two categories of news types above. It's just that Waspada is quite dominant in the news placement of the collapse of Al-Ikhlas Mosque in the news analysis category, reaching 83 percent in contrast to the dominant SIB on news of 83, while the news of the analysis is 17 percent higher than 67 percent analysis. This shows that Alert and Analysis show more attitudes towards mosque collapse because news is more analysis on interviews and management of dominant information from the media agenda/ 
journalists towards or responding to an issue that occurs. Whereas SIB who prefer the placement of news events or with the method of $5 \mathrm{~W}+1 \mathrm{H}$ is more related to the hard SIB reporting model that is motivated by the founder of the newspaper from the Batak ethnic group and the readers are also the majority of Batak / non-Muslim who fit the frank writing style without delay (straight news).

Table 7. News Source

\begin{tabular}{|c|c|c|c|c|c|c|}
\hline INTERVIEWEES & $\begin{array}{c}\text { FREK. } \\
\text { wary }\end{array}$ & PERCENT\% & $\begin{array}{c}\text { FREK. } \\
\text { Analysis }\end{array}$ & PERCENT\% & $\begin{array}{c}\text { FREK } \\
\text { SIB }\end{array}$ & PERCENT\% \\
\hline Government & 4 & 33 & 2 & 22 & 2 & 29 \\
\hline $\begin{array}{c}\text { Community / Non- } \\
\text { Government } \\
\text { Organizations }\end{array}$ & 5 & 42 & 7 & 78 & 5 & 71 \\
\hline Legislative & 3 & 25 & - & - & - & - \\
\hline Total & 12 & 100 & 9 & 100 & 7 & 100 \\
\hline
\end{tabular}

Source: Processed from research data

Table 7 above shows the various groups used by Waspada, Analysis and SIB daily as news sources of the collapse of Al-Ikhlas Mosque on Timor Medan, varying and none of them stand out from the third percentage of newspapers both from government and mass organizations/ non-government. Unless Was Alert made the legislative members of the DPRD or DPD become speakers in the news of the mosque's collapse. Even Waspada in its news analysis unit made legislative members, as political institutions, as sources for stating a kind of support so that the mosque should not be destroyed because it involved a Muslim house of worship. Waspada involving politicians in the hope of not being able to legalize the destruction of mosques in Medan City arbitrarily. Whereas the analysis and SIB that did not involve the legislators in their sources can be said that the two newspapers tended to be "safe looking" and did not want to be dragged too far in the SARA region. Thus only prioritizing formal and non-formal information in the context of the context of events only.

Table 8. Main Issues

\begin{tabular}{|c|c|c|c|c|c|c|}
\hline $\begin{array}{c}\text { NEWS } \\
\text { ISSUES }\end{array}$ & $\begin{array}{c}\text { FREK. } \\
\text { Wary }\end{array}$ & PERCENT\% & $\begin{array}{c}\text { FREK. } \\
\text { Analysis }\end{array}$ & PERCENT\% & $\begin{array}{c}\text { FREK. } \\
\text { SIB }\end{array}$ & PERCENT\% \\
\hline Capitalism & 3 & 21 & - & - & - & - \\
\hline SARA & 5 & 36 & 1 & 17 & - & - \\
\hline $\begin{array}{c}\text { Social } \\
\text { conflict }\end{array}$ & 2 & 14 & 3 & 50 & 5 & 71 \\
\hline $\begin{array}{c}\text { Law } \\
\text { enforcement }\end{array}$ & 4 & 29 & 2 & 33 & 2 & 29 \\
\hline Total & 14 & 100 & 6 & 100 & 7 & 100 \\
\hline
\end{tabular}

Source: Processed from research data

Table 8 reinforces the impression in the previous table, especially Table 10, that the issue of the demolition of the Al-Ikhlas Mosque on Timor is inseparable from the development gap in 
Medan City which can be said to prioritize the addition of physical buildings to pursue regional income, resulting in material mastery by "players business "which has large capital easily just demolish mosques with various kinds of excuses so that the issue of mosque collapse does not only intersect with religion, but also on political, legal, interesting and" dragging "sensitive areas: ethnicity, religion and race (SARA) which invites social conflict. That in turn requires a strict policy from the government, even demanding fair law enforcement in the case of mosque collapse. However, because Waspada has ideological linkages with mosque collapse, the Waspada news puts the capitalism issue at 25 percent, SARA is 36 percent lower than the percentage of social conflict issues on the news of Analysis and SIB of 50 and 71, respectively.

This proves that the two newspapers are not want to be dragged into the SARA region and more likely to seek safety by following events (social conflicts in the field). It's just that the three media put the issue of the mosque collapse on the law enforcement side almost evenly: Be alert 29 percent, Analysis 33 percent and SIB 29 percent. This is also adjusted to the interests of the media and their respective ideologies.

\subsection{Text Analysis of Waspada Daily Discourse, Analysis and Sinar Indonesia Baru}

As determined in the object and subject of the study, the researcher will analyze three news texts that stand out from the news of each newspaper studied. Determination of three news texts is considered to be representative in describing behind the text, especially using the van Dijk model (Eriyanto, 2011). In this context, the researchers determined that the three texts to be analyzed had gone through a news analysis of the three media that had previously been categorized as reporting the collapse of the Al-Ikhlas Mosque on Timor Medan throughout 2012, starting from the number of breaking news, news laying positions, number of paragraphs, types news, news sources and major issues raised. Following is the presentation of the discourse analysis of three texts on the news of the collapse of the Al-Ikhlas Mosque on Timor.

\subsubsection{Waspada Daily}

\section{a. Framing Discourse Analysis}

Title: Hundreds of Muslims Demo Mayor's Office; Demand the Construction of Al-Ikhlas Mosque at its Initial Location

Edition: January 7, 2012

News Location: A3 (city page)

The collapse of the Al-Ikhlas Mosque on Timor was not the first time it happened to the house of worship in Medan City so that the Muslim community affiliated with the Islamic mass organization fought in various ways including demonstrating to the Medan Mayor's Office and suing the party who demolished the mosque to the mosque so that the mosque built in its original location. Islamic mass organizations oppose the demolition of the mosque and field to immediately build the mosque at its original location. The efforts of developers who mastered the mosque's hermitage to be built by the property and Pemko terrain did not act decisively, triggering the anger of Muslims. They asked Pemko Medan not to side with a company which was accused of contributing to the destruction of Al-Ikhlas Mosque on Timor Medan. This was evidenced when the masses urged to meet the Mayor to ask for an explanation of the Medan City Government's firm attitude to be truly concerned with the destruction of the mosque. Finally, the Secretary of Medan admitted that the closing wall at the mosque's hermitage had no permit at the 
urging of the masses during the demonstration. In this news the Waspada Daily really showed its concert to oppose the mosque demolition and wanted the mosque to be rebuilt immediately by revealing the weakness of government policies and law enforcement in accordance with the voices of Islamic organizations. This is supported by elements of the structure of the formation of discourse framing, for example, raising a bold and direct theme on the issues demanded by Islamic organizations. According to van Dijk (Eriyanto, 2012), thematic shows a general description of a text and can also be called a core idea, summary or the main one of a text.

Thematic or topic shows the dominant, central and most important concepts from the side of a news. By raising a bold and assertive topic, the Waspada daily increasingly shows its seriousness to oppose the collapse of the mosque in Medan City. Then, from the schematic aspect of the Alert news text actually makes a complete and unified scheme in presenting the demands of Islamic organizations. Likewise the aspects of background, intent, purpose and presumption in interpreting the news text describe things that are detailed on the side and make explicit and reduce the details of the other side such as the statement of how the Islamic Mass Organization revealed that the construction of Al-Ikhlas Mosque "dead price" must be rebuilt in place initially by asking the Pemko Medan not to defend the entrepreneurs and a strong warning to developers that the Al-Ikhlas Mosque must be rebuilt. "If you want to do business, don't worry about places of worship for Muslims or you will face Muslims. We will act anarchy. The meaning of the text here is more in terms of details, setting and having presuppositions. Van Dijk in Eriyanto (2012: 235) says the setting is a justification for the ideas put forward in a text. Likewise, from the aspect of sentence form and coherence, the use of active sentences is prioritized rather than passive in describing protest actions. Likewise, the placement of the text or the text based on ideology is emphasized in the text of the news in Waspada by quoting the word "dead price" in fighting for the construction of the Al-Ikhlas Mosque at its original location. Finally, Waspada in the news text makes graphic or bold and large on the title and subtitle of the news against the mosque's collapse.

\section{b. News Construction Analysis}

The Waspada Daily provides an adequate agenda (agenda setting) for the news of the collapse of the Al-Ikhlas Mosque. In addition, Alert conducts the selection of facts that are presented strategically and accurately. Likewise, the selection of language symbols (language functions). These three actions, according to Allen D. Grimshaw (1973), as an action taken by media workers when constructing a reality that is evidenced from the content analysis category of the three media conducted by researchers in a quantitative way are descriptive to see the placement of news, number of paragraphs, type of news, news sources and the main issues of the three newspapers studied. In an interview with Deputy Responsible Person (Wapenjab), Waspada Daily H. Sofyan Harahap said, the Waspada Daily indeed showed its concern in the case of the collapse of the Al-Ikhlas Mosque. This is because the majority of Waspada readers are Muslims (96.66\%). According to Sofyan Harahap, it is natural that the oldest newspaper on Sumatra Island is able to construct the reality of events such as giving the portion of news placement, selecting news sources and major issues more ahead with other newspapers. Formation of setting agenda, symbol selection and frame formation is certainly based on various internal and external media interests, both technical, economic, political and ideological. Thus, according to Sofyan Harahap, 
this ideology directly moves the mental and journalism of journalists and Vigilant Editors to carry out the construction actions of the reality of the collapse of the Al-Ikhlas Mosque.

The position of this newspaper that carries out the reality construction action can be seen from the percentage of content analysis between the Waspada Daily with the Analysis and Sinar Indonesia Baru which has a striking difference. For example, from the placement of the news on the front page, Waspada obtained 67 percent while the zero percent analysis and New Indonesia Light were only 2 percent. This means specifically analyzing the news of mosque demolition on the inner (city) page or one hundred percent in other assessment categories as well as Sinar Indonesia Baru for the same category also reaching 67 percent or placing more news on the inner page. Furthermore, the percentage of news types in the category of straight news and news analysis categories, Waspada Daily obtained 83 journalists, experts and observers. Experts often mention news analysis is identical to the agenda of media settings. On the discourse of news text framing, this newspaper is in line with Tuchman's statement in Aris Badara (2011: 23) that language is a conceptualization and narrative tool. That is, the Daily Waspada uses language in construction and even creates ideological constructions by creating themes in the discourse of framing the text against and demanding that the Al-Ikhlas Mosque be built in its original location.

\section{c. Editor's Interpretation Analysis}

The results of the analysis and discourse of framing the news text of the collapse of Al-Ikhlas Mosque are an illustration of the editor's interpretation in carrying out editorial duties. Editors interpret cases of mosque collapse relating to the interests of Muslims as a majority. For that reason the report interprets by setting the agenda for the case. "........ the interpretation of the leader and editor, if the news has an element of events, then Waspada covers it. Then if for example the formation of public opinion related to the news, for example the community finally came and rallied, it was a sign that it was in demand by the community and Waspada itself saw that the demolition or removal of the mosque was legally flawed, so that in the direction of the Waspada news it also supported law enforcement against the collapse of the mosque accordingly demands from the opinions that were built earlier. In addition, Alert wants to put the issue of the mosque's demise down to its true proportions. For example, the developer who took down the mosque said that they had replaced the demolished land and mosque, but it was not in accordance with the law. Then there are coercion in the event of the mosque's demolition so that the community, especially Muslims, are harmed so that the losers in the common sense aspect must be defended, this is part of the policy of the Waspada leader, yes there is. The policy is nuanced or related to the aspirations of Muslims as readers of the majority of Waspada. (Wapemred of the Daily Waspada H. Sofyan Harahap, transcript attached).

Table 9. Discourse on Waspada News Text Framing

\begin{tabular}{|c|c|}
\hline ELEMENT & WACANA \\
\hline Thematic & $\begin{array}{r}\text { Hundreds of Islamic mass organizations went berserk during a } \\
\text { demonstration at the Medan Mayor's Office }\end{array}$ \\
\hline Schematic & In this part of the text the news is sequentially highlighted from the \\
\hline
\end{tabular}




\begin{tabular}{|c|c|}
\hline & $\begin{array}{l}\text { themes raised so that there is no unilateral neglect of the issue being } \\
\text { voiced. "... They burn tires and Ashar prayers congregate. Even they } \\
\text { wanted to lower the red and white flag, but the officers managed to } \\
\text { prevent it. They went berserk because the Pemko Medan did not dismantle } \\
\text { the wall that had covered the location of the mosque. The mass almost } \\
\text { conflict with the officers because they did not meet the Mayor and finally } \\
\text { had to settle for meeting with the Secretary and said he would } \\
\text { immediately dismantle the wall because there was no permit ". }\end{array}$ \\
\hline Semantics & $\begin{array}{l}\text { In this text also gives a lot of detail on one side and makes explicit one } \\
\text { side and reduces the other side details such as "Coordinator of the Alliance } \\
\text { of Islamic Organizations Action Hendra Hidayat stated the collapse of Al- } \\
\text { Ikhlas Mosque on Jalan Timor was not the first to worship in the City. For } \\
\text { that the "dead price" of the mosque that was demolished had to be rebuilt } \\
\text { in its original place by asking the Medan Government not to defend the } \\
\text { authorities and a strong warning to the developers that the Al-Ikhlas } \\
\text { Mosque must be rebuilt. If you want to do business, don't ask Muslim } \\
\text { places of worship or you will face Muslims. We will act anarchically." }\end{array}$ \\
\hline Syntax & $\begin{array}{l}\text { In the text of this news there are many uses of active verbs and coherence, } \\
\text { especially in the actions of Islamic organizations, and the use of passive } \\
\text { words in the mention of objects being sued, such as "Hundreds of } \\
\text { Muslims rampaged during a demonstration." Islam continues to fight for } \\
\text { justice and religious rights. "For that Al-Ikhlas Mosque must be rebuilt." }\end{array}$ \\
\hline Stilistic & $\begin{array}{l}\text { In this news text there are many choice words that are used that tend to be } \\
\text { active verbs in every mass action in conveying their aspirations. }\end{array}$ \\
\hline Rhetorical & $\begin{array}{l}\text { In this news text a lot of emphasis is done through thick and large titles, } \\
\text { there are subtitles and snots in bold "Developer Office Demo" as an } \\
\text { emphasis in the information contained in the news. }\end{array}$ \\
\hline
\end{tabular}

\subsubsection{Daily News Analysis}

\section{a. Discourse Framing Analysis}

Title: Don't be blasphemous and discredited by certain ethnic groups

Edition: 7 February 2012

News Location: Page 4 (City Pages)

In this news text there are two speakers who remind the protesters that they are not cornering and blaspheming certain ethnicities. The resource persons were the Secretary of the North Sumatra Zulkarnain Ansor Youth Movement and the North Sumatra Chairperson of Bakopam Ibnu Hajar. The placement of these two speakers is in line with the background of the organization they lead, who prefer the conducive atmosphere of Medan City by safeguarding religious harmony. Their voices were used by the media to assess the demonstrations related to the demolition of places of worship, even though the expressions were not explicitly stated in the text in the background, they had to respect certain ethnic, ethnic and religious groups who had been the target of opposing protesters during this time. the collapse of the Al-Ikhlas Mosque. This news text shows the agenda of the Daily Analysis setting to respond to the event of the demolition of the Al-Ikhlas Mosque which was dominantly voiced by Muslims and affected the Chinese who were also the owners of the newspaper. This was in line with the Daily News attitude. The analysis was more concerned with soft news reporting and did not want to go too far in the SARA area, despite 
addressing the issue of SARA. This indication can be seen from the absence of background text news in the context of the information conveyed. The analysis does not directly state the attitude of more condescending readers who are predominantly Chinese / business or upper class rather than having to ideologically support the rejection of the demolition of the Al-Ikhlas Mosque on Timor Street.

\section{b. News Construction Analysis}

The reality construction of mosque breaking news in this newspaper is also inseparable from the results of content analysis and discourse framing discourse. The one hundred percent analysis daily did not provide a place (agenda setting), especially the category of news on the main page for the issue of the event of the collapse of the Al-Ikhlas Mosque in Timor Medan Street. On the contrary, a hundred percent analysis puts the news on the inner page (city). In addition, Analysis chooses the facts that are strategically framed appropriately and actual according to the interests of newspapers that are business-validated or far different from Waspada's more consern which is manifested in the construction actions carried out by media workers to the fullest. Likewise with the selection of language symbols (language functions) more meaningful soft news. In an interview with the Daily Editor in Chief, Analysis Warjamil, the analysis did keep the news balanced, because the code of ethics ordered us to be balanced. On the other hand specifically for mosques, this newspaper has outlined a policy. If it is like the case of UISU and the case of HKBP University Nommensen, the analysis refers to Article 8 (KEJ) regarding SARA that the news is related and results in SARA. "Well, we keep it right. So if the public judges the news, there is a mention that they are not brave and want to look safe, that public evaluation is not a problem. It's up to the public to judge how. the public who judged it, whatever. Readers judge it for us not to matter. So, basically we have a policy, we are indeed like that "(Warjamil, Secretary of Editorial Analysis, transcript attached). This paper does not show its concern in the case of the collapse of the Al-Ikhlas Mosque until deep. This is due to the majority of Chinese readers. Thus, the analysis must comply with a policy that puts the middle and upper class readers at the forefront. Naturally, the construction of this media on the reality of the mosque's collapse is based on the internal and external interests of the media, both technical, economic, political and ideological. This ideology directly moves the mental and journalism of journalists and their editors to take action in reality construction in accordance with the interests of the newspaper. Unlike the percentage of news types in the category of straight news and news analysis, the frequency of these newspapers is almost the same as Harian Waspada, where the news of analysis is identical to the media setting agenda related to media policy. The construction of soft news media reality is also evident from the appointment of topics that urge the demonstrators to respect and not corner certain ethnic groups. This news is classified as a type of news analysis printed in large and bold letters as well as headlines throughout the event of the collapse of the Al-Ikhlas Mosque. In addition to the news there are words that are tilted in the news text on the framing discourse. According to van Dijk in Eriyanto (2011) the graphic symbol is the construction of media reality to emphasize and emphasize to the public the importance of the section. The parts that are printed differently are the parts that are important for the communicator who wants the audience to pay more attention to that part. Emphasis on this matter in the text reflects a sense of concern, if the protests continue to occur it can disrupt the existence 
of Chinese ethnicity and smooth business. Of course this is based on the background that has occurred in this country so that it has caused too much prejudice.

\section{c. Editor's Interpretation Analysis}

From the results of the content analysis and discourse the framing of the news text of the collapse of Al-Ikhlas Mosque is an illustration of the editor's interpretation in carrying out the editorial task which also applies in Daily Analysis. Editors interpret cases of mosque collapse as news of routine events that highlight aspects of information rather than mosque meaning as Muslim worship is destroyed. This is because Muslims are not the majority of readers of analysis but ethnic Chinese and business people. For this reason, editors interpret issues that are controversial, ethnic and religious.

Table 10. Discourse on News Text Framing Analysis

\begin{tabular}{|c|c|}
\hline ELEMENT & WACANA \\
\hline Thematic & $\begin{array}{l}\text { Reminding the mass of protesters not to discredit and blaspheme certain } \\
\text { ethnicities. "The Ansor Youth Movement and the Muslim Community } \\
\text { Coordinating Board (Bakopam) reminded the protesters that in their } \\
\text { actions they did not discredit and blaspheme certain ethnic groups". }\end{array}$ \\
\hline Schematic & $\begin{array}{l}\text { This opinion was compiled from the statement of the Secretary of the } \\
\text { North Sumatra Zulkarnaen Ansor Youth Movement and Ibnu Hajar, } \\
\text { Chairperson of the Coordinating Board for the Muslim Community } \\
\text { (Bakopam) of North Sumatra, but did not mention which demonstrations } \\
\text { and places of worship. In the text the news also appealed to people who } \\
\text { were demonstrating but which groups were not mentioned. }\end{array}$ \\
\hline Schematic & $\begin{array}{l}\text { The meaning emphasized in the text of the news is the statement of the } \\
\text { two informants "must uphold the principle of voicing aspirations by not } \\
\text { occupying SARA and so that the apparatus take concrete steps to avoid } \\
\text { greater action and lead to discrediting certain ethnic groups so that } \\
\text { horizontal conflicts do not occur". }\end{array}$ \\
\hline Syntax & $\begin{array}{l}\text { This news text illustrates how to link facts or events with each other by } \\
\text { emphasizing "... do not carry on or particular ethnic and ethnic } \\
\text { blasphemy", "... they conduct demonstrations or demonstrations are the } \\
\text { right of every citizen and group and protected by law "," ... all problems } \\
\text { can be resolved by way of deliberation because the Indonesian people are } \\
\text { people who are happy to solve the problem. " }\end{array}$ \\
\hline Stilistic & $\begin{array}{l}\text { This news text shows attitude and ideology by using the phrase "... don't } \\
\text { let the house of worship issue become an excuse to cause the seeds of } \\
\text { conflict". }\end{array}$ \\
\hline Rhetorical & $\begin{array}{l}\text { This news text uses graphics in "standby" to state: "Multipurpose Ansor } \\
\text { Force (Banser) is ready to be needed to maintain order in religious } \\
\text { life ...". In addition, the large title letters are bold as well as the subtitles } \\
\text { are printed in bold. This shows the highlighted parts, this emphasizes the } \\
\text { importance of the public. }\end{array}$ \\
\hline
\end{tabular}

\subsubsection{Sinar Indonesia Baru Daily News (SIB)}




\section{a. Discourse Framing Analysis}

Title: Head of Regional Police Directly Drops to the Field, Requests Mass Demo of Islamic Organizations Not Anarchist

Edition: March 10, 2012

News Location: Front Page

From the title and lead in the text of this news it has been seen that the Sinar Indonesia Baru Daily puts more emphasis on extracting information and the facts of social conflict from the excesses of the demonstration. The highlight in this text was how North Sumatra's Regional Police Chief helped lead the safeguards of the demonstrations that had been chaotic because the police arrested a demonstrator who later got resistance from the masses. Another thing supports the above argument that Sinar Baru Baru in the text of the news is almost one hundred percent quoting information from the North Sumatra Regional Police Chief or a formal source in the effort to secure the Islamic organizations who are actually opposed to the collapse of the AlIkhlas Mosque and other mosques by developer companies. The police chief said "please demo as long as you are orderly and do not carry out anarchic actions." In this text the news presents fewer portions of the demands of the masses and the oration of rejecting the mosque demolition action. Thus the news text of this newspaper shows that it does not show full attention (consern) to the demands of the protesters to rebuild the mosque which was demolished but this newspaper may be said to choose "look safe" so that it only puts forward the event / conflict. Non-Muslim newspaper owners reinforce the attitude of this newspaper in fear of being trapped in the SARA issue they have experienced in a caricature display.

\section{b. News Construction Analysis}

The construction of the reality of the demolition of the Al-Ikhlas Mosque in the Sinar Indonesia Baru Daily was also the same as the Analysis Daily, but it did not arrive at the "text resistance" against the SARA issue which hit the ethnic owners of the newspaper. The resistance of the text in question Analyzes the setting agenda by using two speakers to convey information that the demonstration must respect and not discredit certain ethnic groups. In the case of a mosque collapse, this newspaper places straight news with a frequency of 5 news or 83 percent the most.

This illustrates the reality that the New Sinar Indonesia Newspaper does not want to be trapped in the controversial aspects of Islamic smell in mosque issues so that this newspaper puts forward the issue of social conflict (riot demonstrations, arson etc.) in the case of mosques especially in demonstrations. Besides that, quoting and describing the information of formal sources is more dominant in the news text. This newspaper is also in its own position in the selection of facts that are presented (strategic framing), as well as the general selection of symbols (language functions) in interpreting the reality of mosque collapse. But this newspaper continues to provide a news site for the collapse of the Al-Ikhlas Mosque on the front page, despite taking a corner of social conflict and putting forward official statements. The reality construction of the demolition of this mosque by "looking safe" was delivered by Sinar Indonesia New Editor, Yogi Swanda: "Yes, indeed we emphasize the events or demonstrations as events that occur in the field, so it does not emphasize the problem or the background of the action, or the effect of the incident. You could say we are looking for safety, huh. Taking into account the background of the SIB owner himself who is non-Muslim. So, we occupy the actual portion. For this reason, the selection of official 
sources (officials) so that the news based on the source is really clear because it involves security as well, including the background of the non-Muslim SIB owners also so that they do not get involved in problems that are considered to discredit Islam. "

\section{c. Editorial Interpretative Analysis}

The Sinar Indonesia Daily Editor only interpreted the event of the Al-Ikhlas Mosque's collapse as an issue that was full of SARA without having to test it with journalistic code because it was related to Islam. "We have no policy, but we must consider and interpret and interpret the things that were mentioned earlier. Just like other Islamic news. As here, we are careful and more vigilant so that there are no more problems that are considered to be SARA. "(Yogi Iswanda, editor of the main SIB page) From this explanation a lot of the meaning of reality as outlined in the text emphasizes not on the background of the problem presented, even ignoring things that are in line put forward in a logic of news schemes, instead the order that becomes unimportant is in the main position of the series of schema compilation in a text news. According to Eriyanto (2011), this fact further emphasizes an editorial interpretation of a report that does not support real reality. There are many more interpretive practices of editors from the news of the demise of this mosque. Even so the editor still interpreted that the case of mosque demolition would still be a news that had to be conveyed to the reader because the value of the conflict meant a newspaper with a straight news presentation model.

Table 11. Discourse on Framing the New Indonesian Sinar News Text

\begin{tabular}{|c|c|c|}
\hline ELEMENT & WACANA \\
\hline Thematic & \begin{tabular}{c} 
The mass of Islamic mass organizations again held a demonstration \\
\hline Schematic
\end{tabular} & $\begin{array}{c}\text { Mass demonstrations carried evidence of mosque demolition in the form of mosque and } \\
\text { madrasa signposts to be installed at the location of the mosque which had been } \\
\text { demolished. The action received resistance from the police so that it arrested an action } \\
\text { coordinator. "... The masses carried out resistance against the arrest of a protester, the } \\
\text { end of the Regional Police Chief Inspector General Wisju Amat Sastro went down to } \\
\text { meet the masses at the location and promised to help the aspirations of the Muslims to } \\
\text { the Governor, after receiving an explanation, the mass broke up". It should be from the } \\
\text { lead / theme, the news sequence is echoed from why Islamic organizations are back in } \\
\text { action. In this text ignores that reason. More inclined to the conflict }\end{array}$ \\
\hline Semantics & $\begin{array}{c}\text { The meaning to be emphasized in the news text related to security and law enforcement } \\
\text { submitted by Kapoldasu "for demonstrators to maintain public order and not to act } \\
\text { anarchistly, if burning tires and carrying out anarchic actions, if burning tires and } \\
\text { carrying out anarchic actions, it does not hesitate to arrest " }\end{array}$ \\
\hline Sintaksis & $\begin{array}{c}\text { The form of sentence used tends to be on the news text that "raises" or prioritizes formal } \\
\text { sources by using the pronoun "me" to the provincial police chief: "I will help this } \\
\text { problem and I will also help the masses to meet the Governor". Likewise the word "we" } \\
\text { in the expression of the action orator from the mass of Islamic organizations: "... we ask } \\
\text { that the demolished mosque be rebuilt". This is to strengthen informal informants in the } \\
\text { action. }\end{array}$ \\
\hline Stilistic & $\begin{array}{c}\text { The choice of words in the news text depicts a conflict process that means ideology in } \\
\text { the demonstration that is imposed by the police on the protesters with the word ": } \\
\text { suddenly an army of police secures one of the action coordinators". }\end{array}$ \\
\hline Rhetorical & \begin{tabular}{l} 
In this news text, emphasis is placed on letters that are skewed on the news connection. \\
\hline
\end{tabular}
\end{tabular}




\section{Conclusion}

The Waspada Daily stated the truth and was most clearly opposed to the collapse of the Al-Ikhlas Mosque. It was seen from the background of the background of the case problem and the discourse of framing the text such as the issue of capitalism (21 percent), SARA (36 percent), social conflict (14 percent), law enforcement (29 percent), news placement on the main page (67 percent ), news analysis (83 percent), sources involving the legislature (25 percent) other than other sources. Daily Analysis reveals this case to be more "safe looking" by ignoring the background of the issue of the collapse and discourse of text framing by placing the issue of capitalism (zero percent), SARA (17 percent), social conflict (50 percent), law enforcement (33 percent ), news placement on the main page (zero percent), news analysis (67 percent), legislative sources (zero percent). The Sinar Indonesia Baru daily reveals this case is similar to the analysis. Satirizing the issue of capitalism (zero percent), SARA (zero percent) and reporting on conflict / higher events (77 percent), law enforcement (29 percent), news placement on the main page (33 percent), news analysis (17 percent), resource person legislative (zero percent). Waspada daily in constructing and interpreting the event of the collapse of Al-Ikhlas mosque is influenced by religious sentiments in the background of newspaper owners (Muslims) and readers who are predominantly Muslim. For this reason, the newspaper interpreted the mosque collapse as a form of injustice, thus increasing reporting from the background and redeeming the SARA zone.

\section{References}

Assegaf, J, 1999. Jurnalistik Masa Kini. Jambatan. Bandung.

Badara, A, 2012. Analisis Wacana; Teori, Metode, dan Penerapannyapada Wacana Media.Kencana Prenada, Jakarta

Bugin, B, 2008. Konstruksi Sosial Media Massa. Kencana Prenada Group

Darma, A.Y, 2009. Analisis Wacana Kritis. Yrama Widya, Bandung

Denzin, N \&Lincoln S.Y, 2000. Handbook of Qualitative Research. Sage Publication Inc, London, New Delhi.

Mulyana, D, \& Solatun, 2007. Metode Penelitian Komunikasi. Rosda Karya, Bandung

Effendy, U.O, 2003. Ilmu, Teori dan Filsafat Komunikasi. Citra AdityaBakti, Bandung.

Eriyanto, 2011. Analisis Wacana, Pengantar Analisis Teks Media. LKIS, Yogyakarta

Iskandar, M, \& Atmakusumah, 2004. Panduan Jurnalistik Praktis. LembagaPers Dr Soetomo, Jakarta.

Ishwara, L, 2011. Jurnalistik Dasar. Kompas, Jakarta

Komala, L, 2009. Ilmu Komunikasi; Perspektif, Proses, dan Konteks.Widya Padjajaran, Bandung.

Kriyantono, R, 2010. Teknik Praktis Riset Komunikasi. Kencana Prenada,Jakarta. 
Kusumaningrat, P, \& Kusumaningrat, H, 2009. Jurnalistik Teori danPraktek. Rosda Karya,Bandung

Littlejohn, W.S \& Foss, A.K, 2011. Teori Komunikasi. Salemba Humanika, Jakarta

McQuail, D, 1991. Teori Komunikasi Massa. Erlangga, Jakarta

Moleong,J.L, 2010. Metodologi Penelitian Kualitatif. RosdaKarya,Bandung

Morrison, Wardhani, C.H., \& Hamid, F, 2010. Teori Komunikasi Massa. GhaliaIndonesia, Bogor

Mufid, M, 2009. Etika Filsafat Komunikasi, Kencana Prenada Group, Jakarta

Mulyana, D, 2007. Metode Penelitian Komunikasi; Contoh-contohPenelitian Kualitatif dengan Pendekatan Praktis. Remaja Rosda KaryaBandung.

Mulyana, D, 2008. Ilmu Komunikasi Suatu Pengantar.RosdaKarya,Bandung

Nurudin, 2007. Pengantar Komunikasi Massa. PT Raja Grafindo Perkasa,Jakarta

Patton, Q.M, 2001. Qualitative Research\& Evaluation Methods. Sage Publication

Putra, S.K.D, 2012. Media dan Politik; Menemukan Relasi Antara Dimensi Simbosis-Mutualisme Medan dan Politik, Graha Ilmu, Yogyakarta.

Robert, M Entman (1993). Framing Toward Clasification of a Fractured Paradigm. Journal of Communication. 43 (2) 51-58

Reese, D.S \& Gandy H.O \& Grant, E.A, 2001. Framing Public Life; Perspective in Media and our Understanding of The Social World. Laurence Erlbann Assocciates, Publisher

Pohan, S, 2010. Disertasi. Universiti Sains Malaysia

Rakhmat, J, 2007. Psikologi Komunikasi. PT Remaja Rosda Karya, Bandung

Samovar, L.A, Porter, E.R., \& McDaniel, R.E, 2010. Komunikasi LintasBudaya. Salemba Humanika, Jakarta

Saverin, J.W., \& Foss, A.K, 2008. Teori Komunikasi, Sejarah, Metode, danTerapan didalam Media Massa. Kencana Prenada, Jakarta

Sugiono, 2001. Metode Penelitian Kuantitatif Kualitatif dan R\&D. Alfabet, Bandung

Tamburaka, A, 2012. Agenda Setting Media Massa. Rajawali Pers, Jakarta. 